\title{
A Severe Disease of Tomato in the Culiacan Area (Sinaloa, Mexico) Is Caused by a New Picorna-Like Viral Species
}

\author{
M. Turina, Istituto di Virologia Vegetale, CNR, Strada delle Cacce 73, 10135 Torino, Italy; M. D. Ricker, Nunhems- \\ USA, Acampo, CA,USA; and R. Lenzi, V. Masenga, and M. Ciuffo, Istituto di Virologia Vegetale, CNR, Strada \\ delle Cacce 73, 10135 Torino, Italy
}

\begin{abstract}
Turina, M., Ricker, M. D., Lenzi, R., Masenga, V., and Ciuffo, M. 2007. A severe disease of tomato in the Culiacan area (Sinaloa, Mexico) is caused by a new picorna-like viral species. Plant Dis. 91:932-941.

We were able to mechanically transmit a small isometric virus from field tomato samples showing severe necrotic symptoms, collected in the Culiacan area of Sinaloa state (Mexico). After gradient purification and three rounds of single-lesion passage on Chenopodium quinoa, the virus was back-inoculated to tomato plants and reproduced the original apical necrosis symptoms. The virus could be transmitted to a wide range of experimental hosts, including a number of solanaceous plants. Purified virus was used to produce specific polyclonal rabbit antibodies and serological tests such as enzyme-linked immunosorbent assay, Western blot analysis, and an immunochromatographic lateral flow assay. Such assays confirmed the wide distribution of this virus in symptomatic field plants in the area of the epidemic. Purified particles contained two genomic RNA molecules of ca. $7 \mathrm{~kb}$ (RNA1) and $5 \mathrm{~kb}$ (RNA2) estimated length. Analysis of clones from a cDNA library provided 6.5 and $3.0 \mathrm{~kb}$ of sequence for RNA1 and RNA2, respectively. Sequence analysis of the encoded replicase showed greatest similarity with members of the Sequiviridae family, and indicated that the virus we isolated is a new virus species, provisionally named Tomato apex necrosis virus.
\end{abstract}

Additional keywords: Solanum lycopersicum

World production of tomato in 2005 amounted to 122.6 MMT (million metric tons), of which 2.14 was produced in Mexico (source: FAO statistics). The tomato crop has basic economic importance to agriculture in Sinaloa state and contributes significantly to Mexican agricultural exports to the United States and Canada. In fact, the Mexican state of Sinaloa depends economically on the export of tomatoes (4), grown mainly during the winter season, and production is limited primarily by diseases, many of them associated with viruses. Whitefly- and thrips-transmitted viruses have been of major concern for the past 10 years. In particular, geminiviruses were found to be widely distributed, and a new geminivirus was isolated from this area $(3,15)$. Tomato spotted wilt virus (TSWV) was shown to be present, possibly with variants having different biological properties $(6,7)$. Locally, the disease is called "marchitez manchada" or "marchitez".

Growers in Sinaloa and Sonora recently suspected the presence of a new strain of

Corresponding author: Massimo Turina

E-mail: m.turina@ivv.cnr.it

Accepted for publication 21 March 2007.

doi:10.1094/PDIS-91-8-0932

(C) 2007 The American Phytopathological Society
TSWV-one that infects tomato cultivars carrying the $S w 5$ resistance gene. Symptoms commonly include necrotic growing apices, elongated necrotic lesions on stems, and less commonly, ringspots on green fruit. Because TSWV is known to cause ringspots on fruit, and some strains can cause stem necrosis, the emerging disease in Mexico was assumed to be a resistance-breaking strain of TSWV by many personnel in the tomato industry. The "marchitez" disease is of major concern in the Culiacan and Sonora states of Mexico, and similar symptoms have also been noted in Baja California (Mexico).

Our initial objective was to show that the causal agent of marchitez on tomatoes carrying the $S w 5$ resistance gene was a new resistance-breaking strain of TSWV. However, TSWV was not found, but instead we isolated and characterized a different causal agent from symptomatic plants, provisionally named VE434. VE434 appears to be a new viral species, probably assignable to an undefined taxon comprising bipartite plant picorna-like viruses.

\section{MATERIALS AND METHODS}

Sample collection, host range analysis, and electron microscopy. Plants expressing virus-associated symptoms were chosen during surveys in 2005 of field tomatoes showing strong necrotic symp- toms on leaf and stem (Fig. 1A to D). Crude sap extracts prepared as previously described (37) and stained with $2 \%$ uranyl acetate were examined using a Philips CM10 electron microscope. Leaf extracts were mechanically inoculated to a range of test plants as previously described (26). Serially diluted infected tomato sap was used to obtain single local lesions on Chenopodium quinoa, and three cycles of mechanical inoculation from single lesions were performed before reinfecting tomato plants. We used Nicotiana benthamiana as the experimental host for the successive characterization steps. Plants were grown in a greenhouse where the temperature was maintained near $26^{\circ} \mathrm{C}$. Lyophilized preparations of the symptomatic leaves were stored at $-80^{\circ} \mathrm{C}$.

Virus purification and antibody production. For each purification, $50 \mathrm{~g}$ of infected $N$. benthamiana was homogenized with $150 \mathrm{ml}$ of $0.25 \mathrm{M}$ potassium phosphate buffer, $\mathrm{pH} 7,0.5 \%$ thioglycolic acid, and $10 \mathrm{mM}$ EDTA. After filtration through cheesecloth, $1 \%$ Triton $X$ and $0.5 \%$ sulphobetaine were added and the solution was stirred for $1 \mathrm{~h}$ at $4^{\circ} \mathrm{C}$, then centrifuged at $10,500 \times g$ for $10 \mathrm{~min}$ at $4^{\circ} \mathrm{C}$. The supernatant was layered onto a $10-\mathrm{ml} 20 \%$ sucrose cushion prepared in extraction buffer (for each 70-ml tube) and centrifuged for $2 \mathrm{~h}$ at $235,000 \times g$ at $4^{\circ} \mathrm{C}$. Each resulting pellet was resuspended overnight in $4 \mathrm{ml}$ of $0.25 \mathrm{M} \mathrm{K}$-phosphate buffer, $\mathrm{pH}$ 7. After centrifugation $(16,000 \times g$ for 10 min), the supernatant was brought to $60 \mathrm{ml}$ and layered onto a $10-\mathrm{ml} 20 \%$ sucrose cushion and centrifuged as outlined above. The pellet was resuspended in $0.5 \mathrm{ml}$ of $0.25 \mathrm{M}$ K-phosphate buffer, $\mathrm{pH} 7.0$, and centrifuged twice at $2,500 \times g$ for $5 \mathrm{~min}$ at $4^{\circ} \mathrm{C}$ before being layered on a 10 to $50 \%$ sucrose gradient in $0.25 \mathrm{M}$ phosphate buffer and centrifuged for $2 \mathrm{~h}$ at $275,000 \times$ $g$. Bands in the region between 1.5 and 4 $\mathrm{cm}$ from the bottom of the tube were collected, diluted 10-fold in the same buffer, and centrifuged at $235,000 \times g$ for $2 \mathrm{~h}$. Purity of the viral suspension was evaluated by electron microscopy and Coomassie brilliant blue staining of proteins separated on a $10 \%$ SDS-PAGE gel (31). Protein concentrations were determined using the Quick StartTM Bradford Dye Reagent (Biorad, Hercules, CA).

New Zealand White rabbits were injected with $1 \mathrm{mg}$ of purified virus emulsi- 

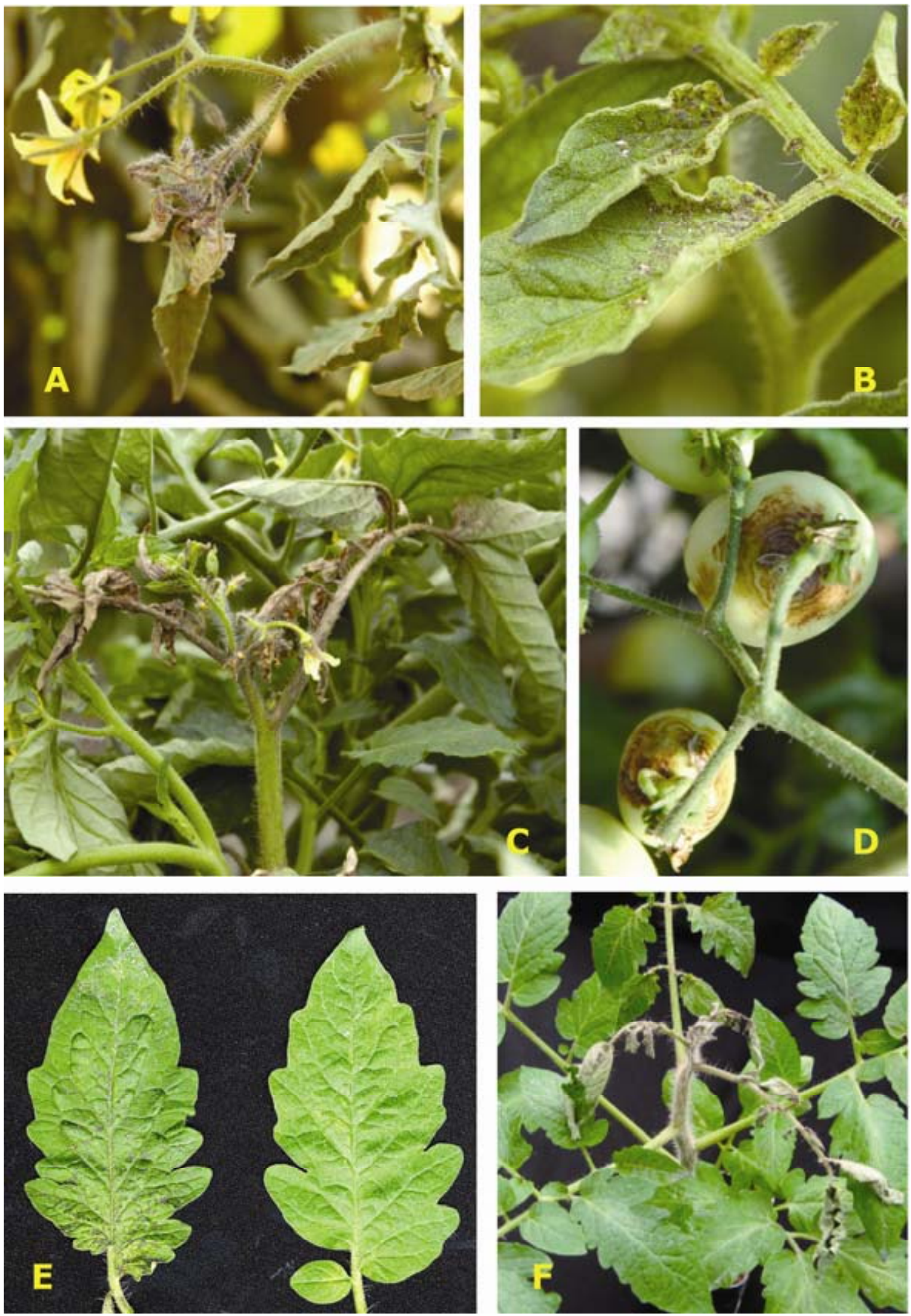

Fig. 1. Symptoms associated with "marchitez" disease in natural infections and after mechanical inoculation with VE434 in controlled environments. A to D, Images of plants in the field taken at the end of the growing season. $\mathbf{A}, \mathbf{B}$, and $\mathbf{C}$ are images of plants from a greenhouse in Culiacan area that were positive for VE434 infection by specific lateral flow device. The plant shown in D (from Obregon, Sonora state) was positive in double-antibody sandwich enzymelinked immunosorbent assay for VE434 and negative for a range of other viruses including Tomato spotted wilt virus. $\mathbf{E}$ and $\mathbf{F}$ show symptoms on tomato plants 3 weeks postinoculation with purified viral isolate VE434 that was obtained from Nicotiana benthamiana after 3 serial passages from single lesions on Chenopodium quinoa. 
fied with Freund's complete adjuvant. Booster injections (up to five) of similar material were repeated every 2 weeks using complete adjuvant. Serum was collected in 2 or 3 bleedings at 2-week intervals beginning 30 days after the first injection.

Enzyme-linked immunosorbent assay (ELISA) and Western blot analysis. Antisera were cross-absorbed with healthy plant extracts and the $\operatorname{IgG}$ fractions were affinity-purified on protein $G$ columns (Pharmacia) as indicated by the manufacturer. Purified $\operatorname{IgG}$ was used for antigen coated plate (ACP)-ELISA and Western blot analysis. Aliquots of IgG were conjugated to alkaline phosphatase as previously described (5) and used for double antibody sandwich (DAS)-ELISA. DAS- and ACPELISA were carried out as previously described, with preliminary trials to establish optimal antibody dilutions $(14,26)$. Total leaf protein extraction, SDS-PAGE, and Western blot analysis were carried out as previously detailed (38). Primary antibodies were used at a 1:2,000 dilution, whereas secondary horseradish peroxidase conjugated antibodies (Sigma-Aldrich, MO, USA) were used at a 1:10,000 dilution.

We also set up a rapid immunochromatographic technique known as Lateral Flow (LF) to be used for preliminary field tests as previously described (28) using colloidal gold-conjugated antibodies. Test lines were made with $1 \mathrm{mg} / \mathrm{ml}$ anti-virus antibody solution and control lines with affinity purified anti-rabbit antibodies from goat (Sigma-Aldrich) at $0.5 \mathrm{mg} / \mathrm{ml}$ and were dispensed with an EasyPrinter (Advanced Microdevices, Ambala, India). HF240 membranes (Millipore, MA, USA) supplied in laminated cards were used.
Absorbent and sample pad (AP22) and glass fiber for the conjugate pad were also from Millipore.

Survey of tomato crops. In June 2006, we collected 54 samples from multiple greenhouses at one location and a field near Obregon (Sonora state, Mexico) showing strong marchitez symptoms. Symptomless samples were included together with some samples of nightshade (Solanum nigrum) and bindweed (Convolvulus arvensis). Samples were processed by DAS-ELISA as described above. A few samples were collected earlier in the season from the Culiacan area of Sinaloa state and checked with VE434-specific LF tests (28).

cDNA library and Northern blot analysis. RNA was extracted from purified virus after dilution of the sample with an equal volume of $2 \times$ STE ( $20 \mathrm{mM}$ Tris-Cl, $\mathrm{pH} 7.5,20 \mathrm{mM} \mathrm{NaCl}$, and $2 \mathrm{mM}$ EDTA) containing $1 \%$ sodium dodecyl sulfate (SDS), two phenol-chloroform extractions, and ethanol precipitation as previously detailed (39). The RNA was further purified by electrophoresis in a $1 \%$ agarose TAE gel using the RNAaid Kit (Bio101, Vista, CA).

A cDNA library was assembled from purified genomic RNA using a new approach: cDNA was prepared with the Universal Riboclone cDNA Synthesis System kit from Promega (Madison, WI, USA) following the manufacturer's advice using both random primers and oligo dT as primers for the reverse transcriptase reaction; next, instead of using EcoRI adaptors included in the kit, a phosphorylated oligonucleotide 'A' (5'-tagtccgaattcaagcaa gagcaca-3') and nonphosphorylated complementary oligonucleotide ' $\mathrm{B}$ ' $(5$ '-ctcttg cttgaattcggacta- $3^{\prime}$ ) were annealed, then

Table 1. Virus symptoms and presence in plant species inoculated with virus isolate VE434

\begin{tabular}{|c|c|c|c|c|}
\hline Family & Species & $\begin{array}{c}\text { Local } \\
\text { symptoms }\end{array}$ & $\begin{array}{l}\text { Systemic } \\
\text { symptoms }\end{array}$ & $\begin{array}{l}\text { DAS-ELISA } \\
\text { results }^{\text {b }}\end{array}$ \\
\hline Amaranthaceae & Gomphrena globosa & 0 & 0 & - \\
\hline \multirow[t]{2}{*}{ Chenopodiaceae } & Chenopodium amaranticolor & nll & 0 & - \\
\hline & C. quinoa & nll & 0 & - \\
\hline \multirow[t]{2}{*}{ Cucurbitaceae } & Cucumis sativus & 0 & 0 & - \\
\hline & Cucurbita реро & 0 & 0 & - \\
\hline Labiatae & Ocimum basilicum & 0 & 0 & - \\
\hline \multirow[t]{9}{*}{ Solanaceae } & Datura stramonium & 0 & $\mathrm{~m}$ & + \\
\hline & Nicotiana benthamiana & 0 & $\mathrm{ym}$ & + \\
\hline & N. clevelandii & 0 & $\mathrm{~mm}$ & + \\
\hline & N. megalosiphon & cll & $\mathrm{m}$ & + \\
\hline & N. glutinosa & 0 & $\mathrm{~m}$ & + \\
\hline & N. tabacum (cv. White Burley) & cll & $\mathrm{mm}$ & + \\
\hline & $\begin{array}{l}\text { Solanum lycopersicum } \\
\text { (cv. Marmande) }\end{array}$ & $\mathrm{nf}$ & $\mathrm{n}$ & + \\
\hline & $\begin{array}{l}\text { Capsicum annuиm } \\
\text { (cv. Quadrato D’Asti) }\end{array}$ & 0 & $\mathrm{ch}$ & + \\
\hline & Solanum nigrum & 0 & $\mathrm{ym}$ & + \\
\hline Apocynaceae & Catharanthus roseus & 0 & $\mathrm{~m}, \mathrm{~d}$ & + \\
\hline Fabaceae & Phaseolus vulgaris (cv. Saxa) & 0 & 0 & - \\
\hline Compositae & Emilia sonchifolia & 0 & 0 & - \\
\hline
\end{tabular}

a Legend: $\mathrm{d}=$ deformation; $\mathrm{cll}=$ chlorotic local lesion; $\mathrm{nll}=$ necrotic local lesion; $\mathrm{m}=$ mosaic; $\mathrm{mm}=$ mild mosaic; $\mathrm{nf}=$ necrotic fleck; $\mathrm{ch}=$ chlorosis; $\mathrm{ym}=$ yellow mosaic; $\mathrm{n}=$ necrosis: $0=$ no symptoms.

b Double-antibody sandwich-enzyme-linked immunosorbent assay on uninoculated leaf samples.

ligated to the cDNA as suggested in the kit. The ligation product was purified from free adaptors by electrophoresing the ligation product in a $1 \times$ TAE agarose gel and purifying cDNA of the desired sizes with the Geneclean II kit (Bio101). After purification, the cDNA was amplified by polymerase chain reaction (PCR) using the ' $\mathrm{B}$ ' oligonucleotide only as primer as previously described (37), with annealing temperature of $51^{\circ} \mathrm{C}$ and extension time of 2 $\min$.

The reaction products were purified as described above and cloned in the pGEM$\mathrm{T}$ easy vector (Promega), and white colonies were screened by PCR using M13 forward and reverse primers. The PCR products were run on a TAE $1 \%$ agarose gel and transferred to a nylon membrane for a slot blot analysis as detailed previously (29); hybridization with a cDNA probe prepared from purified viral RNA and using a digoxigenin (DIG)-labeled UTP was carried out as described by the manufacturer (Roche Diagnostics, Mannheim, Germany). Plasmids with positive inserts were purified from Escherichia coli using minipreps (Qiagen), and the inserts were sequenced using the dideoxy chain termination method (30) with the BigDye Terminator v1.1 Cycle Sequencing Kit (Applied Biosystems, Foster City, CA, USA).

Total RNA from infected tomato and Solanum leaves was prepared through TRIzol homogenization and extraction from leaves as suggested by the manufacturer (Invitrogen, Carlsbad, CA, USA). Reverse transcription was carried out with Omniscript Reverse Transcriptase (Invitrogen) according to the manufacturer's instructions using an oligo(dT) primer. RNA samples were separated under denaturing conditions (glyoxal method) as previously detailed $(29,40)$. BrightStar Biotinylated RNA Millennium Markers (Ambion, Austin, TX, USA) were loaded to estimate genomic RNA length. Northern blot analysis was carried out using a DIGlabeled negative sense RNA probe prepared following the manufacturer's protocols and reagents (Roche Diagnostics). In order to clone viral sequences not identified in the cDNA library, we performed reverse transcription (RT)-PCR using specific oligonucleotides designed from viral cDNA sequences; PCR was carried out using $1 \mu \mathrm{l}$ of the RT reaction in a reaction mix containing 2 units of Taq polymerase (Polymed, Sambuca, Italy) following the manufacturer's protocol with the following cycle: $94^{\circ} \mathrm{C}$ for $4 \mathrm{~min}$, followed by 35 cycles of $94^{\circ} \mathrm{C}$ for $30 \mathrm{~s}, 50^{\circ} \mathrm{C}$ for $30 \mathrm{~s}$, and $72^{\circ} \mathrm{C}$ for $30 \mathrm{~s}$ and a final extension at $72^{\circ} \mathrm{C}$ for $10 \mathrm{~min}$. The PCR product was sequenced directly after purification on Qiagen PCR purification columns.

Overlapping sequences were assembled and open reading frame (ORF) analysis 
was carried out on each sequence using the GCG software package (8). A database search for closely related viral species was carried out using BLAST (1). Predicted amino acid sequences were used for comparison of viral protein sequences with those of representative viruses in the Comoviridae, Fabaviridae, and Sequiviridae present in the GenBank, EMBL, DDBJ, and PDB databases using the CLUSTAL X software version 1.81 (34). Phylogenetic trees were calculated using PROTPARS and PROTDIST together with KITSCH software in the PHYLIP version 3.6 software package (10). Statistical significance was estimated by performing 100 replications of bootstrap resampling of the original alignment using SEQBOOT. A phylogenetic consensus tree was obtained using CONSENSE (majority rule consensus) from the same software package, and the resulting tree was displayed with DRAWGRAM. Alternatively, phylogenetic trees were constructed using the PROML algorithm in the PHYLIP version 3.6 software package (10) using the Dayhoff substitution matrix, one randomized sequence-input order, the global rearrangement option, and a mixed heterogeneity among sites variation model (1 invariable plus 6 Gamma rates). TREE-PUZZLE 5.0 (33) was used to estimate the relative amino acid substitution rates for each category. Statistical significance was estimated by performing 100 replications of bootstrap resampling of the original alignment using SEQBOOT. A phylogenetic consensus tree was obtained using CONSENSE (majority rule consensus) from the same software package, and the resulting tree was plotted with TREEVIEW.

Expression of RNA2-encoded protein fragment in $\boldsymbol{E}$. coli. Given the low level of similarity of the RNA2 fragment-encoded protein to any protein in the databases (for details, see results section), we proceeded to verify if a recombinant protein fragment expressed in E. coli from an RNA2 coding sequence could be recognized by viral antibodies. The 1.8-kb DNA fragment encoding the carboxy terminus of the RNA2 protein was cloned into the BamHI site pRSetC (Invitrogen). This fragment was obtained by RT-PCR under the conditions previously described using the oligonucleotides RNA2-Bam-F (5'-aaaggatccctt caatgggtgctcaaatg-3') and RNA2-Bam-R $\left(5^{\prime}\right.$-aaaggatccagtagcatggtactt- $\left.3^{\prime}\right)$. Subsequently, isolated plasmid cDNA was sequenced across the insertion site to verify in-frame fusion of the histidine tag and the VE434 RNA2 encoded protein. Expression conditions were those described previously (38). Western blot analysis was performed on bacterial lysates using our antiserum diluted 1:4,000 $1 \mathrm{~h}$ after induction with IPTG.

\section{RESULTS}

Virus isolation, symptomatology, and host range. Figure 1A to D shows examples of the primary symptoms of marchitez observed on field tomatoes. The most distinctive symptom is necrosis of growing points (youngest leaflets), resulting in a brown, brittle dieback. The next older leaves sometimes become necrotic as well, but necrosis rarely extends to the main stem. Necrosis of single leaves starts as small dark flecks at the base of leaflets, and eventually the spots coalesce and cover the entire base. Additional symptoms include plant stunting and concentric rings on areas of fruit near the peduncle. Mechanical transmission from field samples to $N$. benthamiana resulted in interveinal chlorosis (data not shown). Electron microscopy of leaf dip extracts from the original samples indicated the presence of isometric particles ca. $30 \mathrm{~nm}$ diameter (data not shown). Similar particles were also present in the inoculated $N$. benthamiana plants. Electron microscopic observation of leaf dip extracts failed to indicate the presence of other viral species commonly infecting tomato, such as Cucumber mosaic virus (CMV), Tomato mosaic virus (ToMV), Tomato spotted wilt virus (TSWV), Potato virus Y (PVY), or Pepino mosaic virus (PepMV). We preliminarily called this new infectious agent VE434. DAS-ELISA for TSWV, Impatiens ne-

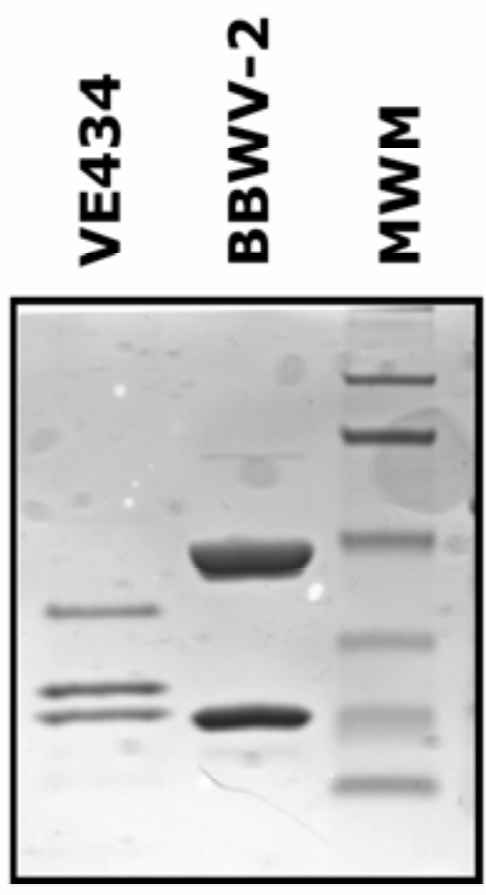

A

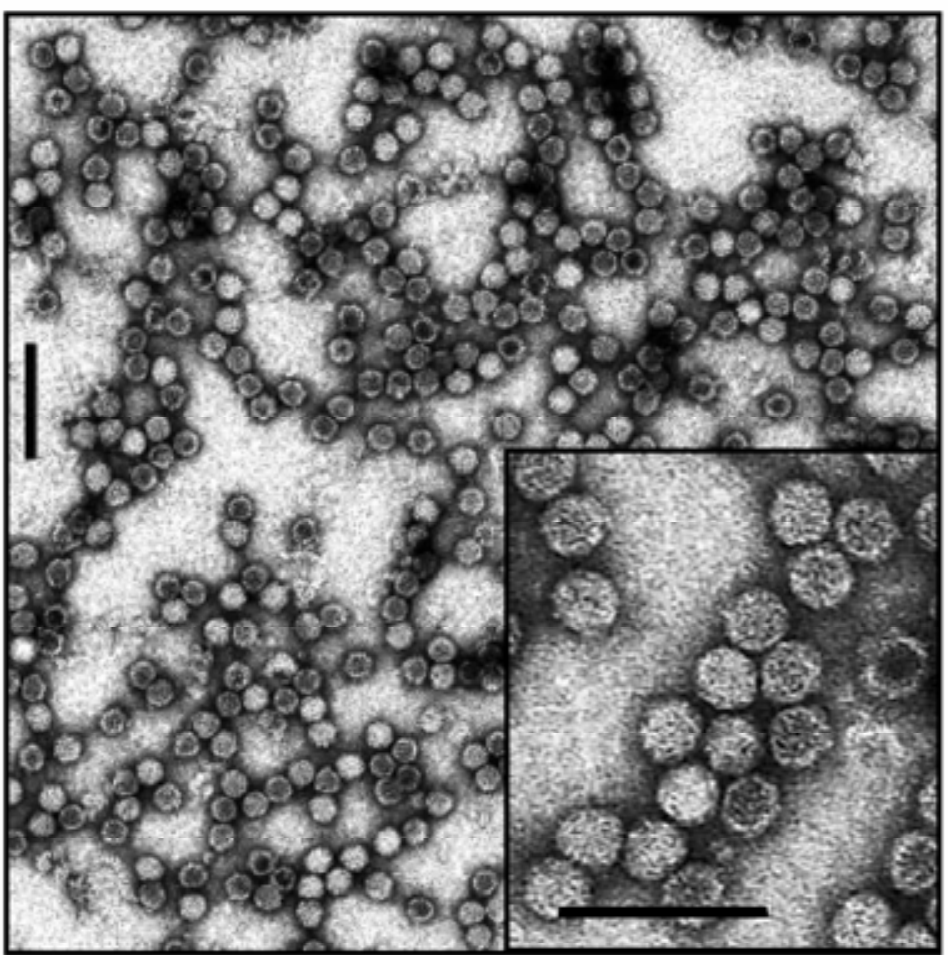

B

Fig. 2. Proteins and particles in purified VE434 preparations. A, Coomassie brilliant blue G250 stained PAGE gel of purified VE34. VE434, $2.5 \mu$ g protein from a VE434 purification electrophoresed as described in the materials and methods. BBWV-2, purified BBWV-2. MWM = molecular weight marker. B, Electron micrograph of negatively stained purified virus. Black bar $=100 \mathrm{~nm}$. Inset represents an enlargement showing empty and full viral shell of uniform diameter. 
crotic spot virus (INSV), CMV, ToMV, and PVY were all negative (data not shown). After finding that $C$. quinoa was a good local lesion host, we purified the virus isolate using a series of three mechanical inoculations from single local lesions at limiting sap dilution. With the final inoculum, we then inoculated a number of host plant species and observed the symptoms were also tested by DAS-ELISA (see below) to detect possible latent infection. The virus infected all of the solanaceous hosts tested, but of these, only Solanum nigrum showed symptom recovery 3 weeks postinoculation.

The tomato cv. Marmande was infected by mechanical inoculation with some difficulty, with slight improvement using However, transmission was erratic, ranging from 10 to $50 \%$ among experiments. Figure $1 \mathrm{E}$ to $\mathrm{F}$ shows symptoms produced by VE434 on tomato plants after mechanical inoculation in a controlled environment. After the apices became necrotic, the plants remained stunted and showed abnormalities that prevented flower and fruit production.

Purification, antibody production, and assessment of diagnostic tools. Generally we were able to recover 0.5 to $1 \mathrm{mg}$ of purified protein antigen from $50 \mathrm{~g}$ of (Table 1). Plants not showing symptoms young plants held in the dark for $24 \mathrm{~h}$.

symptomatic leaves. Sucrose gradients displayed the presence of two major bands at 32 to $35 \mathrm{~mm}$ and 37 to $43 \mathrm{~mm}$ from the bottom of the tube. Purity of the antigen after sucrose gradient centrifugation was evaluated by Coomassie staining of SDSPAGE-separated samples and in negatively stained viral suspensions. Purified virus preparations contained three polypeptides present in approximately equal amounts (Fig. 2A). Their molecular weights, based on mobility relative to the molecular weight marker and to Broad bean wilt virus 2 (BBWV-2) (isolate PV131 from ATCC) structural proteins were: $38.4,28$, and $23.8 \mathrm{kDa}$. The estimated MW for BBWV-2 were 46 and $23.5 \mathrm{kDa}$, whereas genome sequence analysis shows sizes of 44 and $22.2 \mathrm{kDa}(20)$.

In transmission electron microscopy, the purified viral suspension (Fig. 2B) contained empty and full virus particles of 28 to $30 \mathrm{~nm}$ in diameter.

We generated polyclonal antibodies in rabbit to purified virions, and then tested their sensitivity in DAS-ELISA and ACPELISA. The optimal dilution of antiserum for coating and conjugation in DASELISA was $1: 1,000$. The best infected/ healthy absorbance ratio was obtained in ACP-ELISA at an antiserum dilution of 1:10,000 (data not shown). DAS-ELISA gave positive reactions for an infected
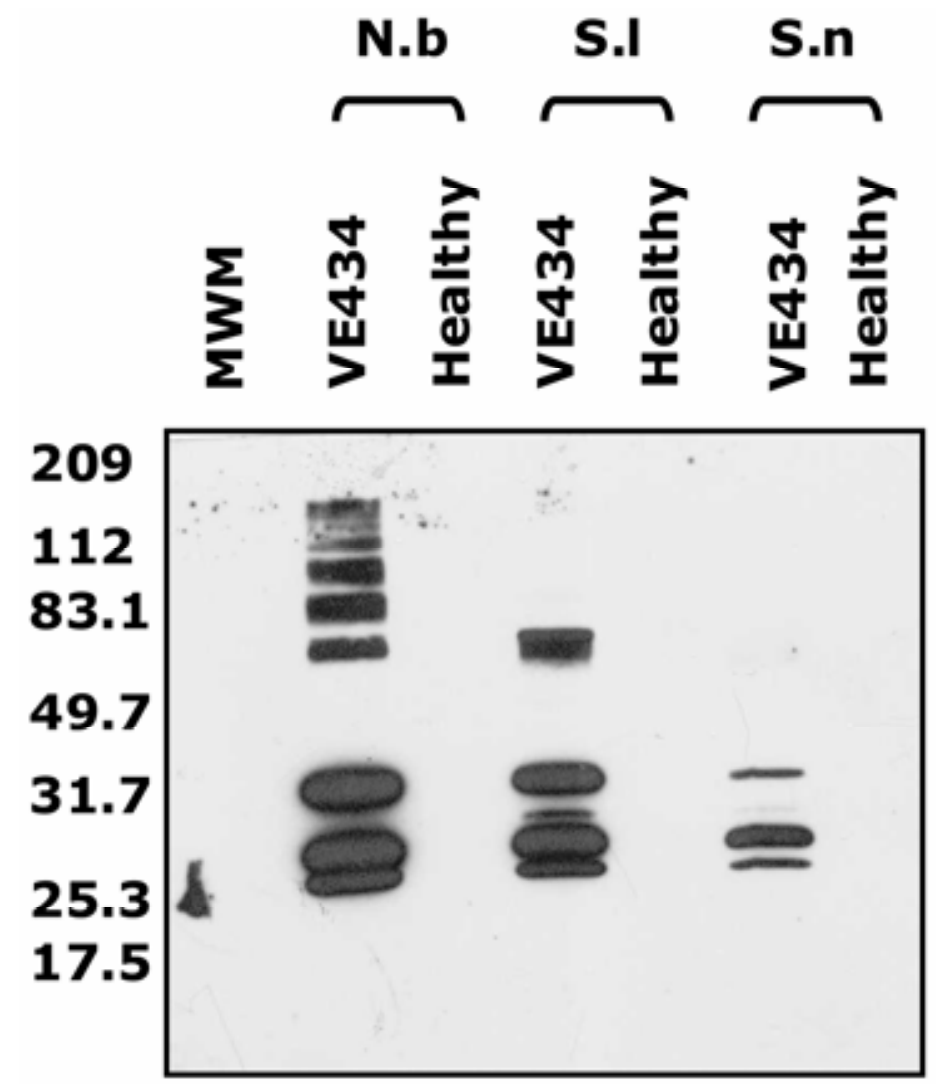

Fig. 3. Chemiluminescent detection of virus isolate VE434 in leaf protein extracts from different plant species by Western blot analysis. Samples were processed as described in the materials and methods section. N.b = Nicotiana benthamiana; S.1 = Solanum lycopersicum; S.n = Solanum nigrum . No substantial differences were seen between extracts from infected and healthy plants on Coomassie blue stained gels. sample up to a dilution of 1:500. Lateral flow devices were also developed which displayed a specific band for infected tomato and $N$. benthamiana plants 2 min after depositing the sample on the pad (not shown).

Western blot analysis produced three major bands of different intensity for extracts from infected plants corresponding to the positions of the three proteins present in purified extracts, plus a number of higher molecular weight bands not present in the corresponding healthy controls (Fig. 3). The high molecular weight bands were particularly pronounced in extracts from infected $N$. benthamiana. Western blots of purified virus displayed reaction with only the three major bands (data not shown).

Molecular characterization and phylogenetic placement. RNA extracted from purified virus and separated in TAE $1 \%$ gel indicated the presence of two RNA molecules, named RNA1 and RNA2 (Fig. 4A). The smaller one (RNA2) was present in greater abundance. When run in denaturing agarose gels, the band corresponding to RNA1 was between the 9- and 6-kb markers, and RNA2 ran close to the $5-\mathrm{kb}$ marker. Gel purified RNA was used as template for a cDNA library, and we obtained a number of clones that hybridized specifically to a viral cDNA probe (data not shown). Two cDNA probes were used for Northern blot analysis, and their position in the genome map is shown in Figure 4D. Probe 14 , comprising the $3^{\prime}$ UTR region of RNA2, reacted with both genomic RNA species, whereas probe 25 reacted only with RNA1 (Fig. 4B and C). Northern blot analysis of total nucleic acids extracted from infected plants failed to show any hybridizing RNA molecule other than the two genomic RNAs (Fig. 4B and C). Sequences of overlapping clones were assembled and deposited in GenBank with accession numbers EF063641 and EF063642. The assembled sequences are about $6.5 \mathrm{~kb}$ for RNA1 and $3 \mathrm{~kb}$ for RNA2. In its 6-kb 3' terminal, the RNA1 fragment encodes for a unique ORF with regions of similarity to viral polymerases of viruses in the lineage of the picorna-like plant viruses. In particular, alignment of previously defined domains I-VII (21) (Fig. 5A) and various phylogenetic analyses indicated that VE434 is most closely related to members of the family $\mathrm{Se}$ quiviridae, but there was no statistically significant clustering (Fig. 5B) with any of the established genera in the family, except a weak homology with the genus $\mathrm{Se}$ quivirus when using the maximum likelihood method. The RNA1 polyprotein could also be aligned to helicase (12) and protease (11) domains showing conservation of the motifs previously identified (not shown).

The 3-kb 3' end of the RNA2 fragment encodes for a single ORF. A BLAST 
search of the various databases using as query the nucleotides or the protein encoded by RNA2 retrieved only some distantly related proteins belonging to Human parechovirus (16) and Rice tungro spherical virus (45). In both cases, the similarity was to viral coat proteins. We therefore tested if at least one of the coat proteins was encoded by the VE434 RNA2. Figure 6 shows that the anti-viral rabbit antibodies reacted specifically with bacterially expressed recombinant protein from the carboxy-terminal part of the protein encoded by RNA2 (72 $\mathrm{kDa}$ predicted molecular weight).

Field survey results. At the end of the winter growing season (June 2006), we tested samples showing marchitez symptoms from Sonora state; we included a few symptomless tomato plants and a few weed samples (Solanum nigrum and Convolvulus arvensis). Of 46 tomato samples, 39 gave positive DAS-ELISA results for VE434 (Table 2). All but two of the positive samples had marchitez symptoms. Of the seven samples negative in DASELISA, only one had "slight" marchitez symptoms. Among the weeds included in the test, three samples of nightshade tested positive for VE434, and these had no symptoms. Lateral flow tests carried out on a limited number of field samples from the Culiacan area of Sinaloa also indicated the presence of VE434 in symptomatic plants, and those results were later confirmed by DAS-ELISA.

\section{DISCUSSION}

Tomato crops are prone to many economically important viral diseases (18), and in addition to the widespread presence of TSWV and various species belonging to the Geminiviridae $(24,27,43)$, various viral species have raised the attention of growers in recent years, including tomato infecting Criniviruses $(42,44)$ and PepMV (23). We report here a new threat to this important horticultural crop.

Farmers from the Culiacan and Ciudad Obregón regions have become accustomed in the last few years to seeing marchitez
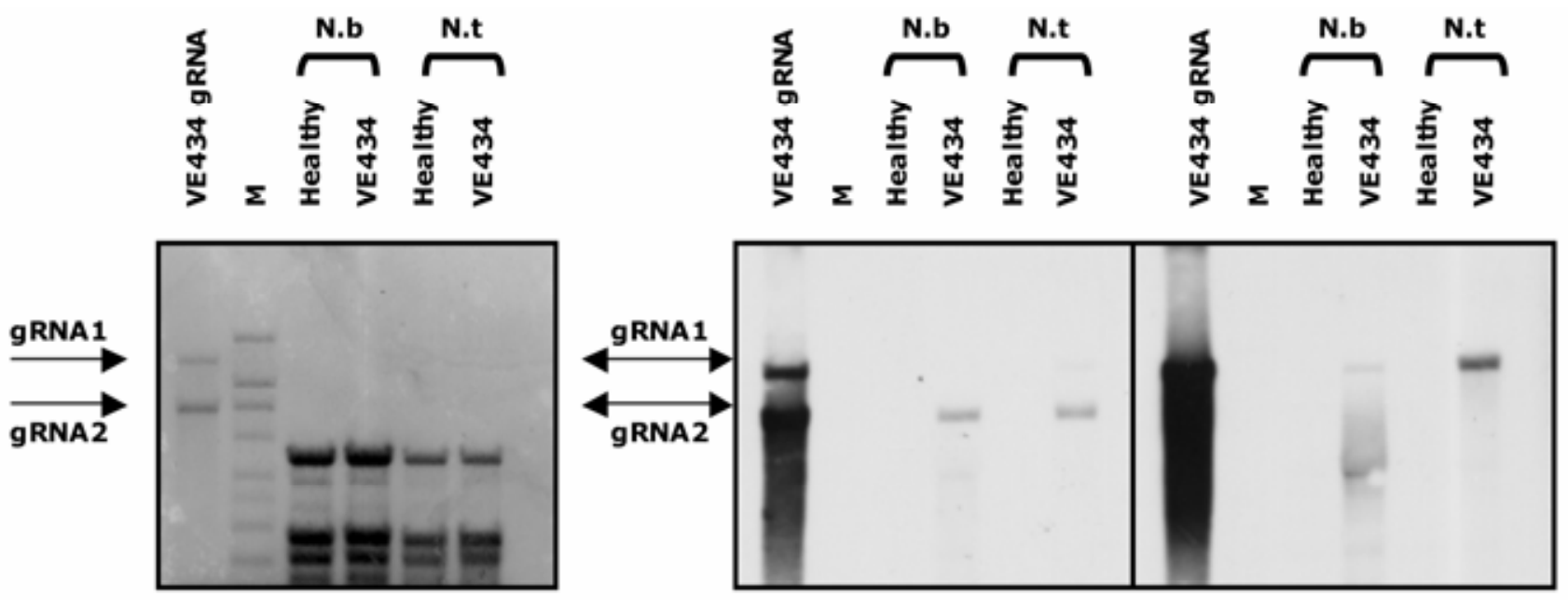

probe\#14

probe\#25

A

B
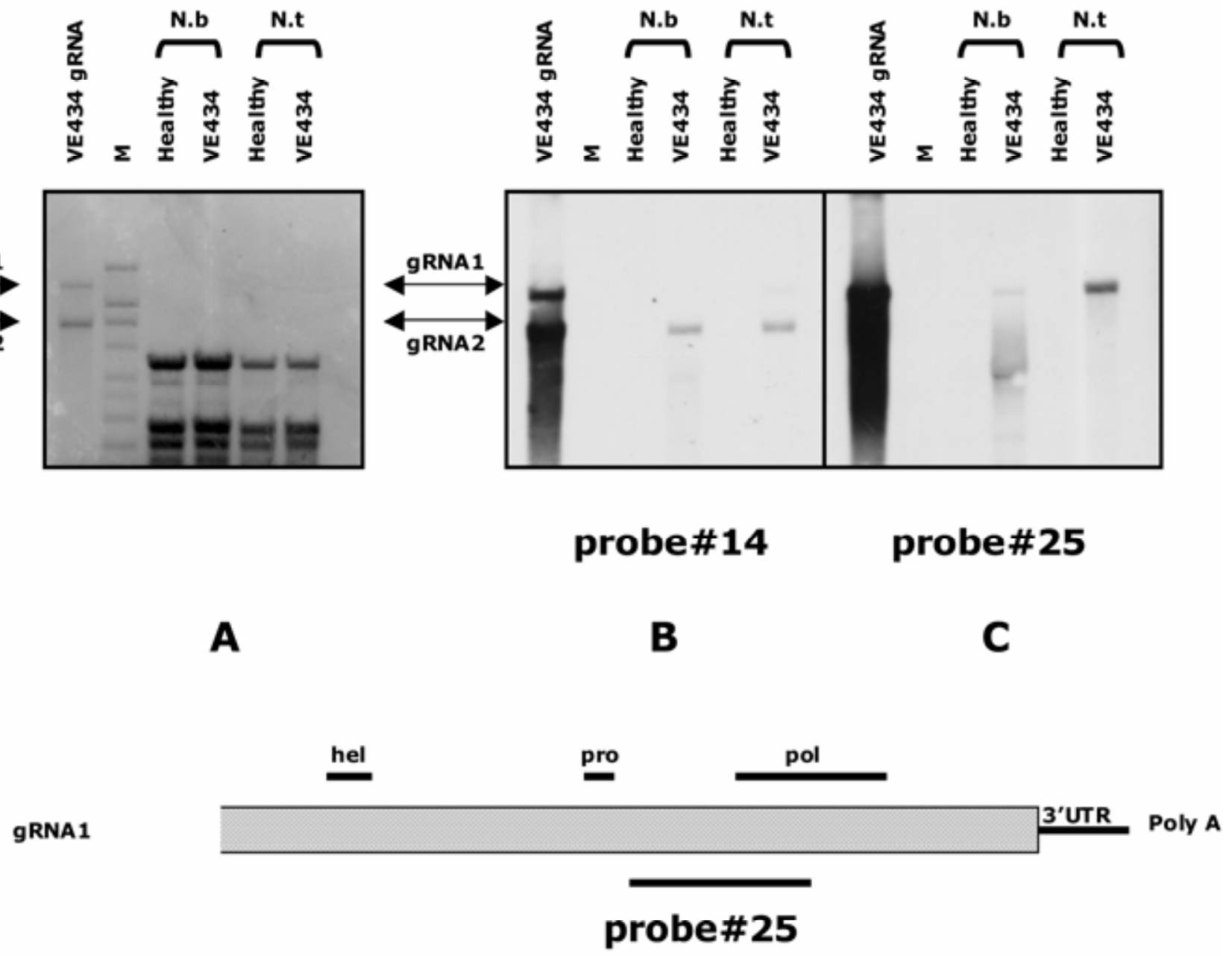

gRNA2

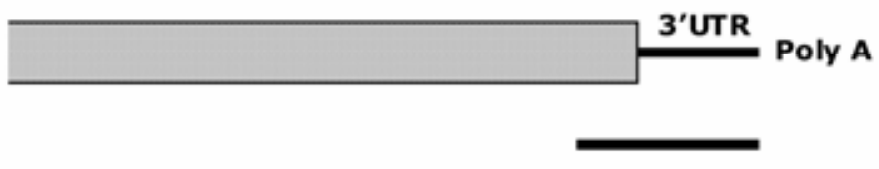

D

\section{probe\# 14}

Fig. 4. VE434 genomic RNA. Wells were loaded with RNA extracted from purified virus samples (gRNA VE434) or from healthy and VE434-infected Nicotiana benthamiana (N.b) and N. tabacum (N.t) plants. A, RNA stained with methylene blue; B and C, chemiluminescent detection of VE434 RNA using digoxigenin labeled RNA probes derived from cDNA clones \#14 and \#25. D, Relative positions of the two clones in the genome together with the polymerase (pol), helicase (hel), and protease (pro) motifs. M = RNA molecular weight marker (top three markers are 9, 6, and 5 kb). Arrows indicate positions of VE434 genomic RNA1 and genomic RNA2. 
symptoms similar to those caused by TSWV, and there are reports of possible new TSWV strains (6). Moreover, a new Tospovirus infecting tomato was recently isolated (13). We failed to detect TSWV by lateral flow devices but were asked to check for the presence of Tospovirus species by electron microscopy (EM). No tospoviruses were found by EM or DASELISA, nor were other viruses commonly found on tomato (CMV, INSV, ToMV, and PVY) found. However, an isometric virus was consistently seen in the preparations which did not react with any of the antisera against isometric viruses commonly infecting tomato (not shown). This implies that the tomato disease that growers generally refer to as "marchitez" is actually caused by at least two unrelated etiological agents: TSWV and a new virus. In our experience, the two viruses have similar symptoms, but VE434 does not seem to cause the yellow rings on tomato fruit, which TSWV often incites.
A

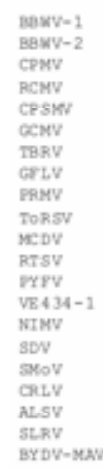

\section{I}

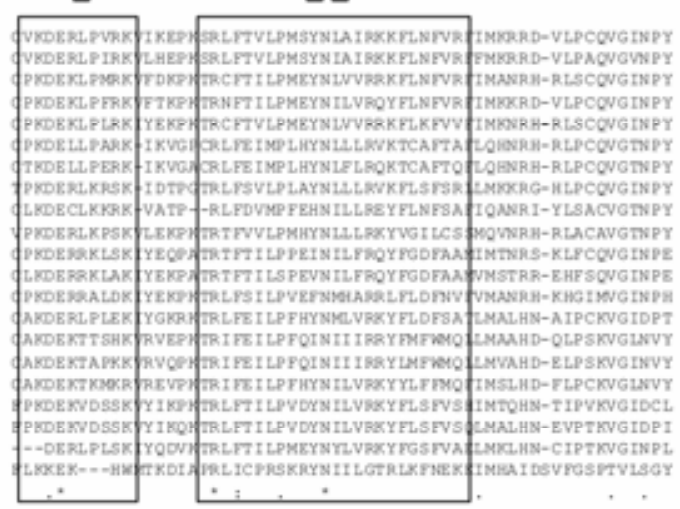

\section{III}

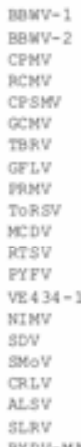

\section{IV}
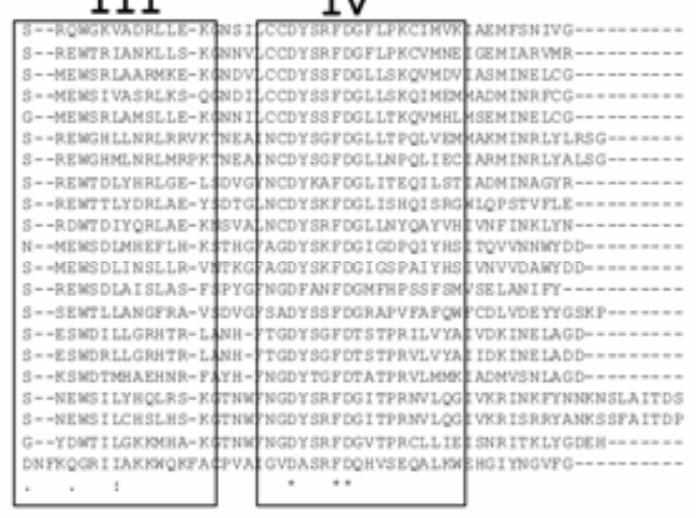

V

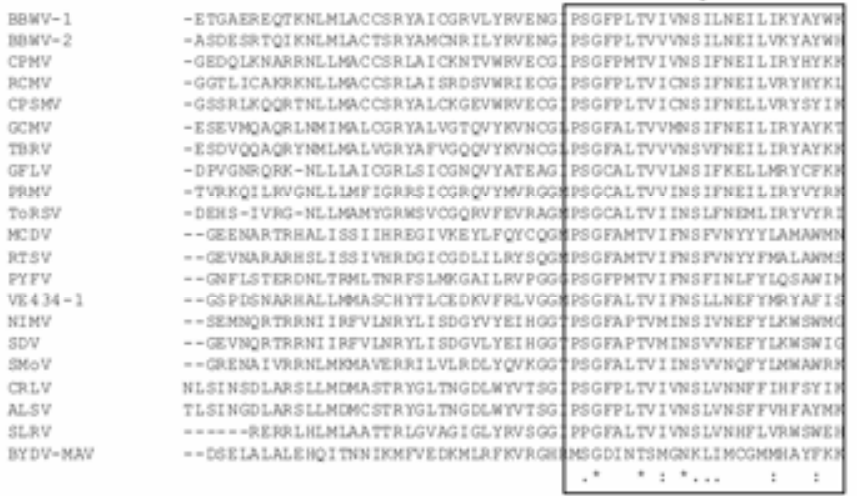

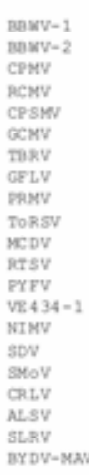

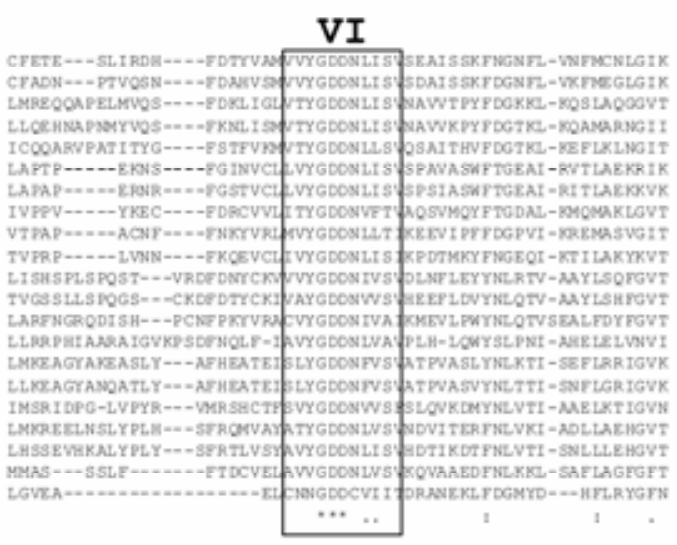

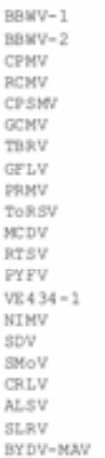

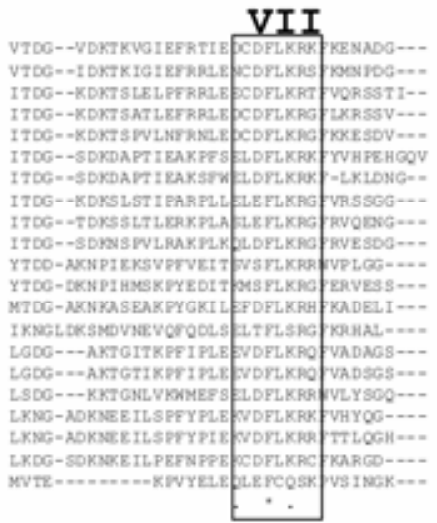

Fig. 5. Open reading frame comparison and phylogenetic analysis of polymerase region of virus isolate VE434. A, multiple alignment of the translated genomic region spanning the 7 polymerase motifs (indicated by black boxes) identified by Koonin (21) for 21 members of the Comoviridae and Sequiviridae. B, Consensus phylogenetic tree obtained from the alignment displayed in A. Numbers on the branches indicate bootstrap values for 100 replications (only those $>70$ are shown). Branches below the threshold have been collapsed to polytomy. The tree shown was generated using PROTPARS and CONSENSE functions of PHYLIP. Barley yellow dwarf virus-MAV (BYDV-MAV) (D01212) was used as an outgroup. Viruses analyzed, their GenBank accession numbers and acronyms are: Apple latent spherical virus (ALSV) (AB030940), Broadbean wilt virus 1 (BBWV-1) (AB084450), Broadbean wilt virus 2 (BBWV2) (U65984), Cherry rasp leaf virus (CRLV) (AY764390), Cowpea mosaic virus (CPMV) (X00206), Cowpea severe mosaic virus (CPSMV) (M83830), Grapevine chrome mosaic virus (GCMV) (X15346), Grapevine fanleaf virus (GFLV) (D00915), Maize chlorotic dwarf virus (MCDV) (U67839), Navel orange infectious mottling virus (NIMV) (Q9YZ97), Parsnip yellow fleck virus (PYFV) (D14066), Peach rosette mosaic virus (PRMV) (AF016626), Red clover mottle virus (RCMV) (X64886), Rice tungro spherical virus (RTSV) (AM234049), Satsuma dwarf virus (SDV) (AB009958), Strawberry latent ringspot virus (SLRV) (AY860978), Strawberry mottle virus (SMoV) (AJ311875), Tomato black ring virus (TBRV) (D00322), Tomato ringspot virus (ToRSV) (L19655). 
Two approaches were applied to fulfill Koch's postulates for this new virus: sucrose gradient purification and evaluation of the purified prep suggested that we had isolated the causal agent, although theoretically the presence of more than one isometric virus cannot be ruled out. The second step was single local lesion passage. After serially applying both procedures, the purified virus was still able to reproduce disease with symptoms very similar to those observed in the field. A survey of field samples also indicated a close association between the disease and the presence of VE434 in Sinaloa and Sonora states. The few exceptions could be accounted for by latent infections. We thus suggest that VE434 is the cause of marchitez in Sinaloa, and that this virus be named Tomato apex necrosis virus (ToANV). Given the sensitive and specific diagnostic tools we have assembled, it will be of interest to test the many areas where similar symptoms are present.

Our claim that ToANV is previously undescribed relies on the absence in the various databases of sequences close enough to be included with this virus in the same species, and on the absence in the literature of isometric viruses causing similar symptoms on tomato. A tomato-infecting nepovirus was reported from Indiana (USA). This virus was not sufficiently characterized to allow for direct comparison, but it has a different host range from ToANV $(2,18)$.

In the last few years, a group of plant viruses has been recognized as picorna-like $(9,17,19,22,25,32,35,36,41)$. This lineage of plant viruses was established in the early 1990s $(32,41)$. These viruses all have isodiametric shells containing three differ-

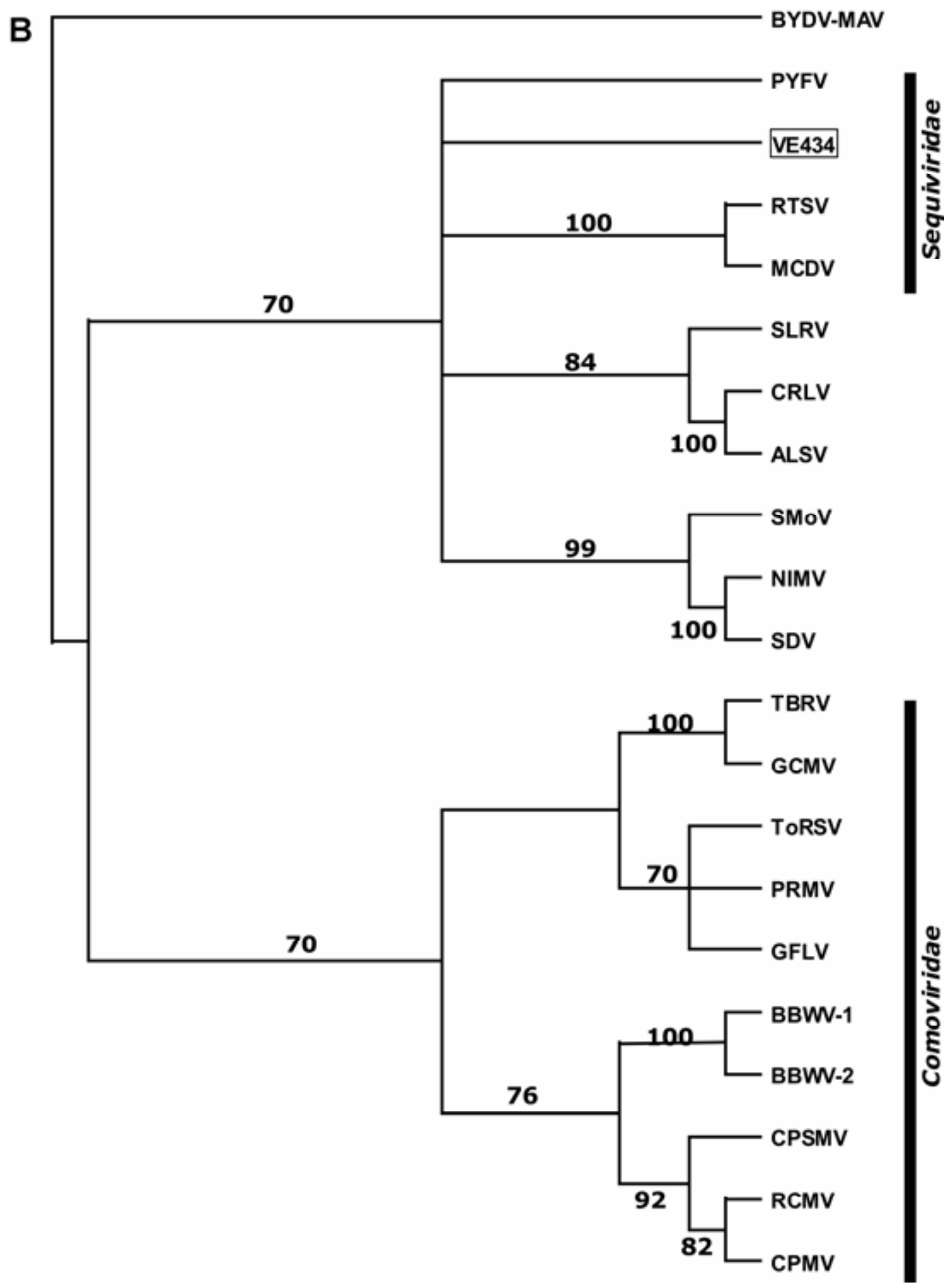

Fig. 5. (Continued from previous page) 
ent proteins, and have phylogenetic relatedness to animal picornaviruses, such as cardioviruses and rhinoviruses, in various regions of the genome $(25,32,41)$. In the last decade, a number of bipartite isometric viruses were also shown to have picorna- like features (9). We provided structural molecular and phylogenetic evidence that ToANV is part of this virus clade comprising members of the family Sequiviridae, and members of the Sadwavirus and Cheravirus genera (Fig. 5).
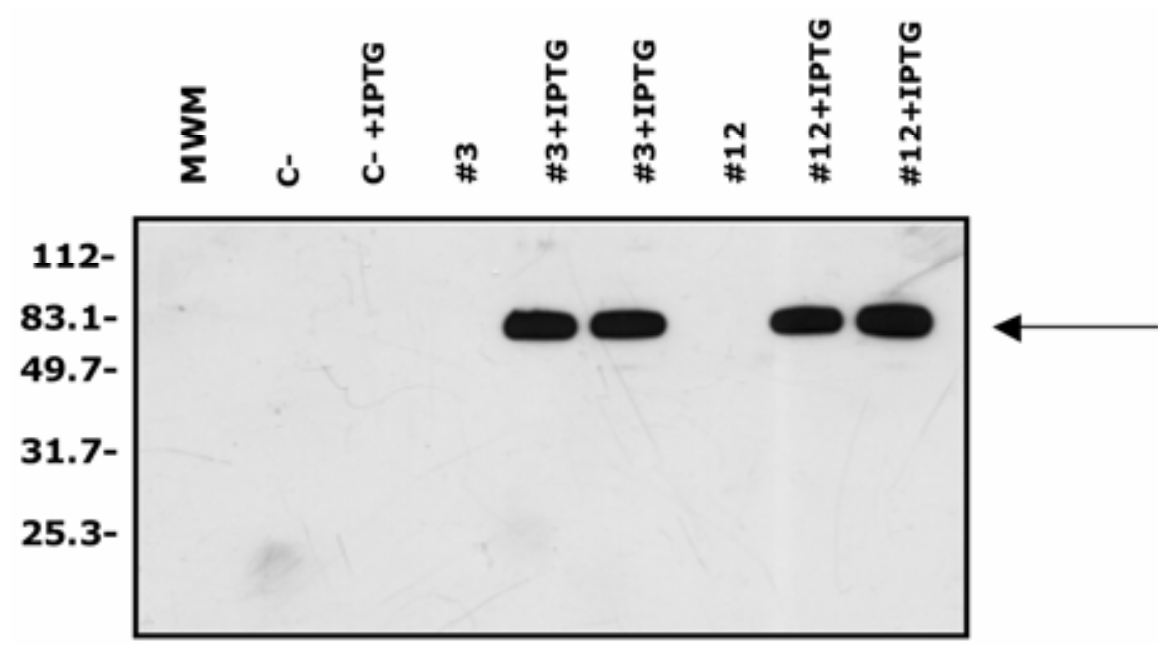

Fig. 6. Western blot analysis (ECL detection method) of bacterial lysate extracts expressing a recombinant fragment of VE434 RNA2. Bacterial cultures from two independent colonies (\#3 and \#12) of Escherichia coli transformed with a plasmid designed to express the C-terminus of the protein encoded by RNA2 (see material and methods) were harvested $1 \mathrm{hr}$ after adding IPTG (+IPTG). Controls with no IPTG were harvested at the same time. Lane $\mathrm{C}$ contained extract from a bacterial colony carrying the expression plasmid with the cDNA inserted in the minus sense direction. The sizes of molecular weight standards are indicated at the left of the panel. No substantial differences were seen between extracts from control and induced bacteria on Coomassie stained gels.

Electrophoresis of viral RNA and Northern blot analysis indicated that ToANV has two genomic RNAs. The hybridization of probe 14 with both genomic RNAs is caused by the fact that this probe contains a 553-bp region of the RNA2 $3^{\prime}$ UTR that is identical to the very $3^{\prime}$ end 553 bp of RNA1. The protein encoded by RNA1 from ToANV has highest similarity with monopartite members of the $\mathrm{Se}$ quiviridae such as Rice tungro spherical virus (RTSV) and Maize chlorotic dwarf virus (MCDV). When the protein sequence of RNA2 is used for comparison, only the similarity to RTSV is confirmed. Similarity to members of the Cheravirus and Sadwavirus genera is also high, if we limit the comparison to the RNA1 polyprotein. This is of interest, because a proposed cheravirus infecting potato was recently characterized (36). ToANV RNA2 size is more similar to that of sadwaviruses than cheraviruses. Some authors support the need for a new taxon comprising all the plant picorna-like viruses $(19,36)$, and we agree with this. So far, members of this clade have been shown to be transmitted by nematode, aphid, and leafhopper vectors (9). Whiteflies and aphids were present throughout the growing season in the fields where we collected samples, but their involvement in marchitez epidemics is not known. Given the severity of the

Table 2. Absorbance value (ABS) in double-antibody sandwich-enzyme-linked immunosorbent assay (DAS-ELISA) for field samples collected at the end of June 2006 from Obregon (Sonora state, Mexico)

\begin{tabular}{|c|c|c|c|c|c|c|c|}
\hline Sample $^{\mathbf{a}}$ & Host species $^{b}$ & $\mathbf{A B S}^{\mathbf{c}}$ & Symptoms $^{d}$ & Sample $^{\mathbf{a}}$ & Host species $^{b}$ & $\mathbf{A B S}^{\mathbf{c}}$ & Symptoms $^{d}$ \\
\hline 1 & Bindweed & 0.01 & None & 29 & Tomato & 0.08 & Slight \\
\hline 2 & Nightshade & 0.01 & None & 30 & Tomato & 0.09 & Severe \\
\hline 3 & Nightshade & 0.10 & None & 31 & Tomato & 0.20 & Slight \\
\hline 4 & Tomato & 0.46 & Slight & 32 & Tomato & 9.19 & Slight \\
\hline 5 & Tomato & 0.08 & Slight & 33 & Tomato & 0.26 & Severe \\
\hline 6 & Tomato & 0.20 & Slight & 34 & Tomato & 0.66 & Slight \\
\hline 7 & Tomato & 0.36 & Severe & 35 & Tomato & 0.50 & Severe \\
\hline 8 & Tomato & 0.73 & Slight & 36 & Tomato & 0.11 & Severe \\
\hline 9 & Tomato & 0.26 & Severe & 37 & Tomato & 0.07 & Gemini-like \\
\hline 10 & Tomato & 1.17 & Slight & 38 & Tomato & 0.01 & None \\
\hline 11 & Tomato & 0.37 & Severe/moderate & 39 & Tomato & 0.01 & Gemini-like \\
\hline 12 & Tomato & 0.01 & None & 40 & Tomato & 0.02 & None \\
\hline 13 & Tomato & 0.15 & None & 41 & Tomato & 1.95 & Slight \\
\hline 14 & Tomato & 0.54 & Slight & 42 & Tomato & 1.82 & Severe \\
\hline 15 & Tomato & 0.21 & Severe & 43 & Tomato & 0.30 & Severe \\
\hline 16 & Tomato & 0.41 & Severe & 44 & Tomato & 0.47 & Severe \\
\hline 17 & Tomato & 0.18 & Severe & 45 & Tomato & 0.12 & Slight \\
\hline 18 & Tomato & 0.29 & Slight & 46 & Nightshade & 1.05 & None \\
\hline 19 & Tomato & 0.62 & Slight & 47 & Tomato & 1.29 & Slight \\
\hline 20 & Tomato & 0.10 & Severe & 48 & Nightshade & 0.02 & None \\
\hline 21 & Tomato & 0.25 & Gemini-like & 49 & Tomato & 0.01 & None \\
\hline 22 & Tomato & 0.82 & Slight & 50 & Tomato & 0.01 & Gemini-like \\
\hline 23 & Tomato & 0.81 & Slight & 51 & Tomato & 0.25 & Severe \\
\hline 24 & Tomato & 0.16 & Slight & 52 & Tomato & 0.32 & Slight \\
\hline 25 & Tomato & 0.06 & Slight & 53 & Inf. benth. & 0.15 & Moderate \\
\hline 26 & Tomato & 0.12 & Slight & 54 & Healthy tom. & 0.01 & None \\
\hline 27 & Bindweed & 0.01 & None & 55 & Healthy tom. & 0.01 & None \\
\hline 28 & Tomato & 0.09 & Slight & 56 & Nightshade & 0.09 & None \\
\hline
\end{tabular}

${ }^{a}$ Samples 1 and 56 were collected from a field covered with sun reducing netting; samples 2 and 3 were collected from an open field; samples 4 to 53 were collected from tomatoes grown in insect-resistant screenhouses adjacent to the open field; samples 54 and 55 were collected from healthy tomato plant controls maintained in a glasshouse in Italy.

${ }^{\mathrm{b}}$ Inf. benth. is a mechanically infected Nicotiana benthamiana plant 2 weeks after inoculation, whereas healthy tom. refers to symptomless plants of Solanum lycopersicum obtained from commercial seed of cv. Marmande and grown in insect-proof greenhouse.

${ }^{\mathrm{c}}$ Samples were considered positive if the absorbance at $405 \mathrm{~nm}$ was more than 3 times that of healthy control plants (highlighted).

d The phrase "gemini-like" refers to typical leaf curl and dwarfing symptoms caused by tomato geminiviruses in the absence of "marchitez" symptoms. 
disease, its high incidence in the fields surveyed, and the potential for epidemic development, more research to understand the epidemiology of disease caused by ToANV is warranted so that appropriate disease control measures can be developed.

\section{ACKNOWLEDGMENTS}

We thank Caterina Perrone for skilful technical assistance in the laboratory and greenhouse, and Robert Milne for critically reading and editing the manuscript. We also thank J. Lorenzo Jimenez Rios and Juan Pablo Zamora for their tireless assistance in Mexico.

\section{LITERATURE CITED}

1. Altschul, S. F., Gish, W., Miller, W., Myers, E. W., and Lipman, D. J. 1990. Basic local alignment search tool. J. Mol. Biol. 215:403-410.

2. Bancroft, J. B. 1968. Tomato Top Necrosis Virus. Phytopathology 58:1360-1363.

3. Brown, J. K., Idris, A. M., and Fletcher, D. C. 1993. Sinaloa tomato leaf curl virus, a newly described geminivirus of tomato and pepper in west coastal Mexico. Plant Dis. 77:1262.

4. Calvin, L. 2004 NAFTA Tomato Dumping Cases. In: Keeping the Borders Open. R. M. A. Loyns, Karl Meilke, Ronald D. Knutson, and Antonio Yunez-Naude, eds. Proc. 8th Agric. Food Policy Systems Inform. Workshop (March 2002). Friesen Printers, Winnipeg, Canada.

5. Clark, M. F., and Adams, A. N. 1977. Characteristic of the microplate method of enzymelinked immunosorbent assay for the detection of plant viruses. J. Gen. Virol. 34:475-483.

6. De la Torre, A. R., Cervantez, L., Houston, H. A., and Valverde, R. A. 2002. Phenotypic variation of some Mexican isolates of Tomato spotted wilt virus (TSWV). Agrociencia 36:211-221.

7. De la Torre, A. R., Teliz, O. D., Barron, B. L., Cardenas, E., Garcia, L. E., Cardenas, M., and Valverde, R. A. 1995. Detection of a viral complex in tomatillo Physalis ixocarpa in the Central High Plateau of Mexico. Phytopathology 85:509.

8. Devereux, J., Haeerli, P., and Smithies, O. 1984. A comprehensive set of sequence analysis programs for the VAX. Nucleic Acids Res. 12:387-395.

9. Fauquet C. M., Mayo, M. A., Maniloff, J., Desselberger, U., and Ball, L. A. 2005. Virus taxonomy. Pages 793-806 in: Rep. ICTV, 8th. Academic Press, New York.

10. Felsenstein, J. 1989. PHYLIP-phylogeny inference package (version 3.2). Cladistics 5:164-166.

11. Gorbalenya, A. E., Donchenko, A. P., Blinov, V. M., and Koonin, E. V. 1989. Cysteine proteases of positive strand RNA viruses and chymotrypsin-like serine proteases. A distinct protein superfamily with a common structural fold. FEBS Lett. 243:103-114.

12. Gorbalenya, A. E., Koonin, E. V., and Wolf, Y. I. 1990. A new superfamily of putative NTPbinding domains encoded by genomes of small DNA and RNA viruses. FEBS Lett. 262:145148.

13. Hassani-Mehraban, A., Saijer, J., Peters, D., Goldbach, R., and Kormelink, R. 2005. A new tomato-infecting tospovirus from Iran. Phytopathology 95:852-858.
14. Heinze, C., Roggero, P., Sohn, M., Vaira, A.M., Masenga, V., and Adam, G. 2000. Peptidederived broad-reacting antisera against tospovirus NSs-protein. J. Virol. Methods 89:137-146.

15. Idris, A. M., and Brown, J. K. 1998. Sinaloa tomato leaf curl geminivirus: Biological and molecular evidence for a new subgroup III virus. Phytopathology 88:648-657.

16. Ito, M., Yamashita, T., Tsuzuki, H., Takeda, N., and Sakae, K. 2004. Isolation and identification of a novel human parechovirus. J. Gen. Virol. 85:391-398.

17. James, D., and Upton, C. 2005. Genome segment RNA1 of a flat apple isolate of Cherry rasp leaf virus: Nucleotide sequence analysis and RT-PCR detection. Arch. Virol. 150:14691476.

18. Jones, J. B., Jones, J. P., Stall, R. E., and Zitter, T. A., eds. 1991. Compendium of Tomato Diseases. American Phytopathological Society, St. Paul, MN.

19. Karasev, A. V., Han, S. S., and Iwanami, T. 2001. Satsuma dwarf and related viruses belong to a new lineage of plant picorna-like viruses. Virus Genes 23:45-52.

20. Koh, L. H., Cooper, J. I., and Wong, S. M. 2001. Complete sequence and phylogenetic analyses of a Singapore isolate of broad bean wilt fabavirus. Arch. Virol. 146:135-147.

21. Koonin, E. V. 1991. The phylogeny of RNAdependent RNA polymerases of positive-strand RNA viruses. J. Gen. Virol. 72:2197-2206.

22. Li, C., Yoshikawa, N., Takahashi, T., Ito, T., Yoshida, K., and Koganezawa, H. 2000. Nucleotide sequence and genome organization of apple latent spherical virus: A new virus classified into the family Comoviridae. J. Gen. Virol. 81:541-547.

23. Pagan, I., Cordoba-Selles, M. D., MartinezPriego, L., Fraile, A., Malpica, J. M., Jorda, C., and Garcia-Arenal, F. 2006. Genetic structure of the population of Pepino mosaic virus infecting tomato crops in Spain. Phytopathology 96:274-279.

24. Pico, B., Diez, M. J., and Nuez, F. 1996. Viral diseases causing the greatest economic losses to the tomato crop. 2. The Tomato yellow leaf curl virus - A review. Sci. Hortic. 67:151-196.

25. Reddick, B. B., Habera, L. F., and Law, M. D. 1997. Nucleotide sequence and taxonomy of maize chlorotic dwarf virus within the family Sequiviridae. J. Gen. Virol. 78:1165-1174.

26. Roggero, P., Masenga, V., and Tavella, L. 2002. Field isolates of Tomato spotted wilt virus overcoming resistance in pepper and their spread to other hosts in Italy. Plant Dis. 86:950-954.

27. Rosello, S., Diez, M. J., and Nuez, F. 1996. Viral diseases causing the greatest economic losses to the tomato crop. 1. The Tomato spotted wilt virus - A review. Sci. Hortic. 67:117150.

28. Salomone, A., Mongelli, M., Roggero, P., and Boscia, D. 2004. Reliability of detection of citrus tristeza virus by an immunochromatographic lateral flow assay in comparison with ELISA. J. Plant Pathol. 86:43-48.

29. Sambrook, J., Fritsch, E. F., and Maniatis, T. 1989. Molecular Cloning: A Laboratory Manual. Cold Spring Harbor Laboratory, Cold Spring Harbor, NY.

30. Sangers, F., Nicken, S., and Coulson, A. R. 1977. DNA sequencing with chain-terminating inhibitors. Proc. Natl. Acad. Sci. USA 74:5463-5467.

31. Shagger, H., and von Jagow, G. 1987. Tricinesodium dodecyl sulfate-polycrilamide gel electophoresis for the separation of protein in the range from 1 to $100 \mathrm{kDa}$. Anal. Biochem. 166:368-379

32. Shen, P., Kaniewska, M., Smith, C., and Beachy, R. N. 1993. Nucleotide sequence and genomic organization of Rice tungro spherical virus. Virology 193:621-630.

33. Strimmer, K., and von Haeseler, A. 1996. Quartet puzzling: A quartet maximumlikelihood method for reconstructing tree topologies. Mol. Biol. Evol. 13:964-969.

34. Thompson, J. D., Higgins, D. G., and Gibson, T. J. 1994. CLUSTAL W: Improving the sensitivity of progressive multiple sequence alignment through sequence weighting, positionspecific gap penalties and weight matrix choice. Nucleic Acids Res. 22:4673-4680.

35. Thompson, J. R., Leone, G., Lindner, J. L., Jelkmann, W., and Schoen, C. D. 2002. Characterization and complete nucleotide sequence of Strawberry mottle virus: A tentative member of a new family of bipartite plant picorna-like viruses. J. Gen. Virol. 83:229-239.

36. Thompson, J. R., Perry, K. 1., and De Jong, W. 2004. A new potato virus in a new lineage of picorna-like viruses. Arch. Virol. 149:21412154.

37. Turina, M., Ciuffo, M., Lenzi, R., Rostagno, L., Mela, L., Derin, E., and Palmano, S. 2006. Characterization of four viral species belonging to the family Potyviridae isolated from Ranunculus asiaticus. Phytopathology 96:560566.

38. Turina, M., Desvoyes, B., and Scholthof, K.-B. G. 2000. A gene cluster encoded by Panicum mosaic virus is associated with virus movement. Virology 266:120-128.

39. Turina, M., Maruoke, M., Monis, J., Jackson, A. O., and Scholthof, K.-B. G. 1998. Nucleotide sequence and infectivity of a full-length cDNA clone of Panicum mosaic virus. Virology 241:141-155.

40. Turina, M., Prodi, A., and Van Alfen, N. K. 2003. Role of the Mf1-1 pheromone precursor gene of the filamentous ascomycete Cryphonectria parasitica. Fungal Gen. Biol 40:242-251.

41. Turnbull-Ross, A. D., Mayo, M. A., and Murant, A. F. 1993. Sequence analysis of the parsnip yellow fleck virus polyprotein: Evidence of affinities with picornaviruses. J. Gen. Virol. 74:555-561.

42. Vaira, A. M., Accotto, G. P., Vecchiati, M., and Bragaloni, M. 2002. Tomato infectious chlorosis virus causes leaf yellowing and reddening of tomato in Italy. Phytoparasitica 30:290-294.

43. Varma, A., and Malathi, V. G. 2003. Emerging geminivirus problems: A serious threat to crop production. Ann. Appl. Biol. 142:145-164.

44. Wintermantel, W. M., Wisler, G. C., Anchieta, A. G., Liu, H. Y., Karasev, A. V., and Tzanetakis, I. E. 2005. The complete nucleotide sequence and genome organization of $\mathrm{To}^{-}$ mato chlorosis virus. Arch. Virol. 150:22872298.

45. Zhang, S., Jones, M. C., Barker, P., Davies, J. W., and Hull, R. 1993. Molecular cloning and sequencing of coat protein-encoding cDNA of Rice tungro spherical virus - A plant picornavirus. Virus Genes 7:121-132. 